\title{
PROBLEMS ASSOCIATED WITH THE AMS DATING OF SMALL BONE SAMPLES: THE QUESTION OF THE ARRIVAL OF POLYNESIAN RATS TO NEW ZEALAND
}

\author{
T F G Higham ${ }^{1} \bullet$ R E M Hedges ${ }^{1}$ A J Anderson ${ }^{2}$ C B Bronk Ramsey ${ }^{1}$ B Fankhauser ${ }^{2}$
}

ABSTRACT. We have AMS dated samples of Pacific rat (Rattus exulans) bone "collagen" and filtered gelatin samples from the prehistoric site of Shag River Mouth, New Zealand. The age of occupation of this site has previously been determined based on 50 radiocarbon measurements. The site dates to the late Archaic phase of southern New Zealand prehistory (about 650-500 BP; 14th-15th century AD). The results of rat bones which we have dated produce a range in ages, from about 980-480 BP, a difference we attribute to a combination of effects. Pretreatment appears to be an important variable, with results showing differences in ${ }^{14} \mathrm{C}$ age between the progressive "collagen" and filtered gelatin chemical treatment stages. Amino acid profiles suggest there is a proteinaceous but non-collagenous contaminant which is removed by the more rigorous pretreatment. Stable isotopes vary between pretreatments, supporting the removal of a contaminant, or contaminants. Variation in $\delta^{15} \mathrm{~N}$ values imply a range in uptake of dietary protein, and might suggest a potential influence from the local aquatic environment or the consumption of marine-derived protein. Rats are opportunistic, omnivorous mammals, and, therefore, obtain carbon from a variety of reservoirs and so we ought to expect that in environments where there is a variety of reservoirs, these will be exploited. Taken together, the results show that rat bone AMS ${ }^{14} \mathrm{C}$ determinations vary in comparison with the established age of the site, but are in notably better agreement with non-collagenous data than in previously published determinations (Anderson 1996).

\section{INTRODUCTION}

Accelerator mass spectrometry (AMS) radiocarbon determinations of the Pacific rat (Rattus exulans) from New Zealand non-archaeological cave contexts have been used to date initial human contact, because rats are a human commensal (Holdaway 1996). The results obtained were significantly earlier than the dates of earliest human settlement established from archaeological contexts (Anderson 1991; Higham et al. 1999). AMS-dated rat bone from sites in both the North and South Islands demonstrated the presence of rats and, therefore, of human contact with New Zealand from about AD 150 (Holdaway 1996). Holdaway (1996) has emphasized that this is not equivalent to permanent settlement, since no archaeological sites have been discovered which date to this period. AMS dates obtained from archaeological rat bones, on the other hand, have produced results which range from reliable to completely erroneous (see Anderson 1996; Beavan-Athfield et al. 1999; Higham and Petchey 2000). Results from the archaeological sites of Pleasant River and Shag River Mouth, for instance, produced dates which were significantly at odds with ${ }^{14} \mathrm{C}$ measurements obtained using reliable samples such as charcoal and shell carbonate (Anderson 1996; Smith and Anderson 1998). In contrast, AMS results of rat bones from the Pauatahunui site (Beavan-Athfield et al. 1999) were in statistical agreement with other reliable sample determinations (estuarine shell). In this paper, we present new data from the Shag River Mouth site which sheds further light on the question of the reliability of rat bone AMS ${ }^{14} \mathrm{C}$ determinations and the reasons for variation from expected values.

Several key issues have been central to the rat bone controversy and attempts to resolve it. First, there is the question of the preservation state of rat bone. Preservation state may be assessed chemically using a suite of analytical parameters, some of which are described below (and see also van Klinken 1999). Holdaway and Beavan (1999) argued that bone from "natural" sites may be differ-

\footnotetext{
${ }^{1}$ Oxford Radiocarbon Accelerator Unit, Research Laboratory for Archaeology and the History of Art, University of Oxford, Oxford OX1 3QJ, England.

${ }^{2}$ Department of Archaeology and Natural History, Research School of Pacific and Asian Studies, Australian National University, Canberra ACT 0200, Australia.
}

(C) 2004 by the Arizona Board of Regents on behalf of the University of Arizona Proceedings of the 18th International Radiocarbon Conference, edited by N Beavan Athfield and R J Sparks RADIOCARBON, Vol 46, Nr 1, 2004, p 207-218 
entially better preserved compared with bone from archaeological sites. This, they argue, is largely due to site taphonomy. Bone from coastal archaeological midden sites may be trampled, burned, and left open to the elements for periods. This results in bone which Holdaway and Beavan (1999) claim is largely unsuited for ${ }^{14} \mathrm{C}$ dating, hence the variation in the rat bone dates from archaeological sites. This contrasts with rat bones from "natural" cave contexts (as in Holdaway 1996) which are wellpreserved. Second, there is the question of whether variable ${ }^{14} \mathrm{C}$ ages are the result of dietary variation amongst rats, how large this reservoir effect could conceivably be, and whether this can be corrected for using stable isotope analysis.

\section{The Shag River Mouth Site}

Shag River Mouth is an archaeological site located at the mouth of the Shag or Waihemo River near Palmerston in North Otago, New Zealand (Figure 1). Midden and putative house/hut sites (represented by hearths) cover about 2 ha of the large sand dune and spit, which extends some $600 \mathrm{~m}$ in a northeasterly direction from an outcrop of Tertiary rocks (McFadgen 1996). Prehistoric evidence has been identified at the edge of the nearby estuary and within the adjacent Sarcocornia-dominated mud flats (Anderson et al. 1996a). The faunal spectrum includes a wide range of marine and terrestrial fauna. The artifactual material recovered is typical of the late Archaic phase of New Zealand culture. The most extensive excavation undertaken at the site took place in 1988 where a $10 \times 10 \mathrm{~m}$ square was opened on the highest part of the dune (SM/C:Dune) (Figure 1). The material described in this paper comes from this area (Anderson et al. 1996a).

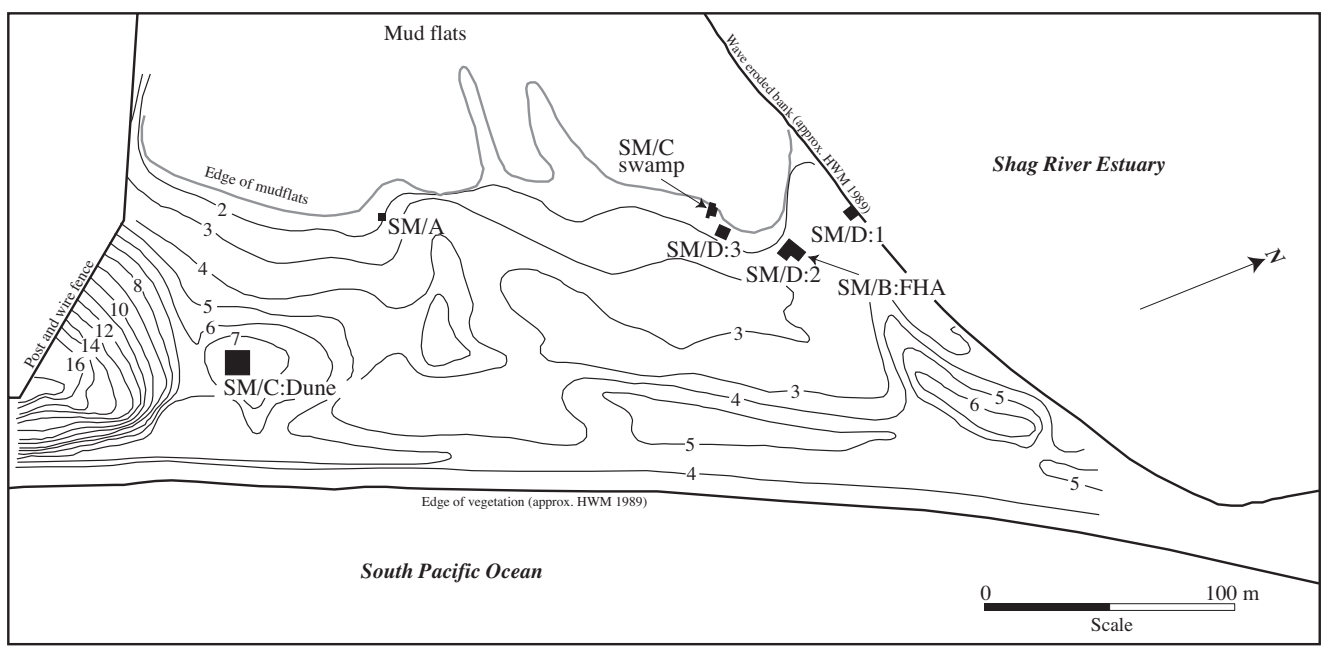

Figure 1 Excavated areas at the Shag River Mouth site, New Zealand. Rat bones dated from the site all come from the SM/C:Dune area (figure adapted after Anderson et al. 1996a). Contours are meters asl.

Fifty ${ }^{14} \mathrm{C}$ determinations have now been obtained from the site (Anderson et al. 1996b) (Figure 2). Taken together, the results of determinations on materials such as identified charcoal and marine and estuarine shell, provide support for occupation beginning in the 14th century AD. The implication of the ${ }^{14} \mathrm{C}$ results and the stratigraphic record is that prehistoric occupation may have been brief (Anderson et al. 1996b). This chronology and the presence of rat bones within cultural layers make the site ideal for testing the reliability of the material for ${ }^{14} \mathrm{C}$, if it can be established that the bone is of reasonable preservation. Previous determinations obtained from this site by Anderson (1996) were highly variable (Figure 2) and no satisfactory explanation for them has yet been provided. 


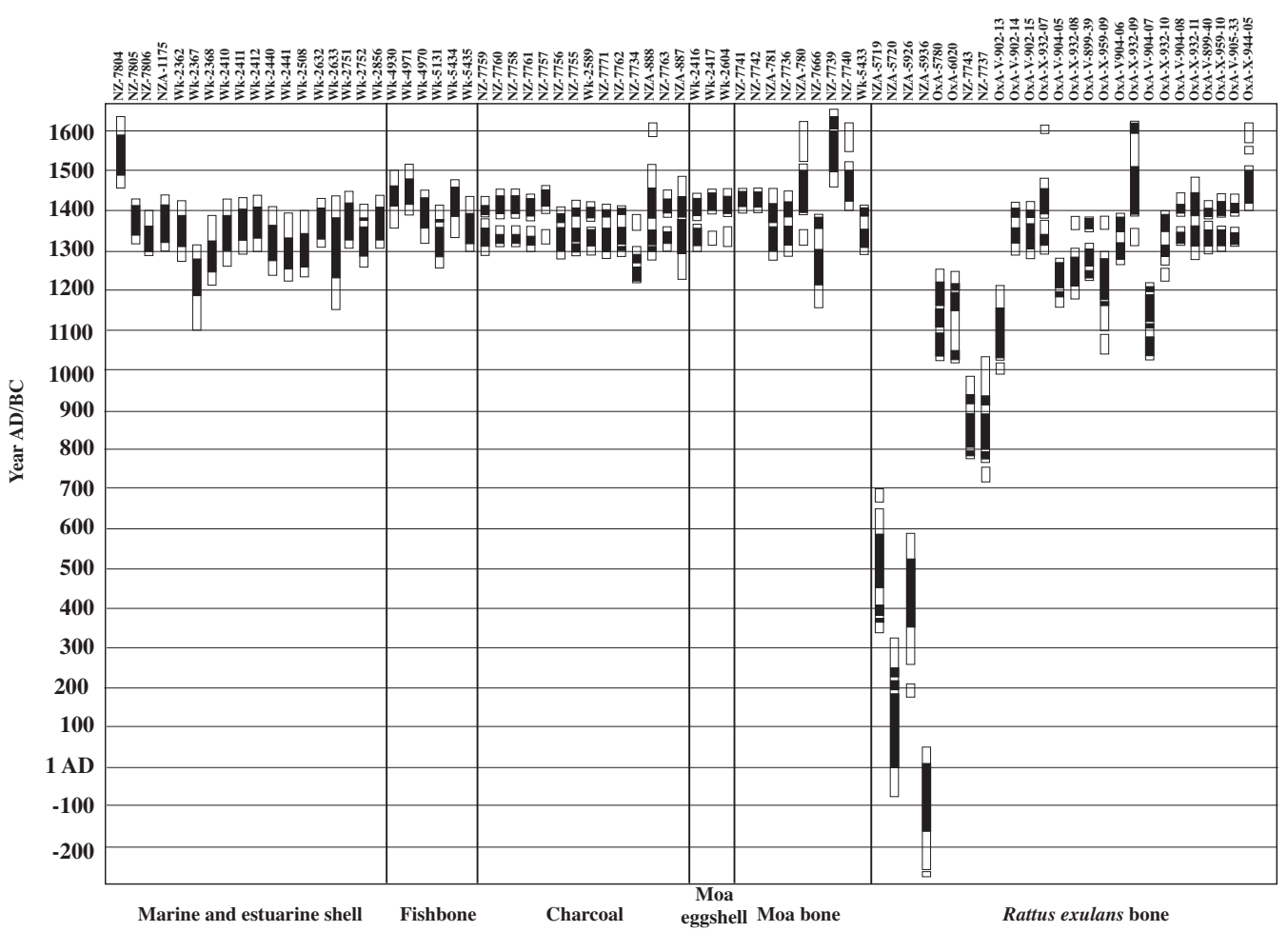

Figure 2 Calibrated age ranges of ${ }^{14} \mathrm{C}$ determinations from the Shag River Mouth site, New Zealand. Data are taken from Anderson et al. (1996b); Higham (1993, 1994); Petchey (1998); Petchey and Higham (2000); Anderson (1996). The estuarine and marine shell, and the fish bone determinations were calibrated using the 1998 marine modelled calibration curve with a $\Delta \mathrm{R}$ offset of $-25 \pm 15 \mathrm{yr}$ applied (Higham and Hogg 1995). The terrestrial materials younger than about 1000 BP were calibrated using the Southern Hemisphere terrestrial curve (Hogg et al. 2003) and those older than about 1000 BP were calibrated using INTCAL98 (Stuiver et al. 1998) with a Southern Hemisphere offset of $27 \pm 5 \mathrm{yr}$ applied after McCormac et al. (1998).

\section{METHOD}

We aimed to investigate questions of contamination in rat bones from the site, in order to determine whether the earlier series could be influenced by old carbon contamination. Therefore, we implemented 2 pretreatment procedures on individual bones: a simple collagen extraction and the isolation of filtered gelatin. It ought to be said that neither pretreatment is our routine method, which is ultrafiltration, but the small starting weights of the rat bones meant this was not able to be implemented. The collagen fraction was dated to determine the influence of potential contaminants compared with gelatinization. We obtained 10 samples of rat bone from the SM/C:Dune site for ${ }^{14} \mathrm{C}$ analysis (Sample reference 8 to 17; Table 1). Individual elements were used for analysis. The bones were pretreated initially at the Australian National University. They were cleaned by scraping with a scalpel to remove soil coloration, sediment detritus, and weathered surfaces, washed 3 times in MilliQ ${ }^{\mathrm{TM}}$ water and centrifuged, then dried at $35^{\circ} \mathrm{C}$ for 3 days. Bones were powdered, decalcified with $\sim 10 \mathrm{~mL}$ of $2 \% \mathrm{v} / \mathrm{v} \mathrm{HCl}$, and dehumified with $0.025 \mathrm{M} \mathrm{NaOH}$ (Figure 3). These "collagen" samples (we use this term in quotation marks after DeNiro and Weiner [1988] and van Klinken [1999]) were submitted to the Oxford Radiocarbon Accelerator Unit (ORAU) for combustion and AMS measurement. In Table 2, they are denoted with "XB" pretreatment codes. 
Table 1 Whole bone samples from Shag River Mouth, New Zealand, selected for ${ }^{14} \mathrm{C}$ dating.

\begin{tabular}{clllr}
\hline $\begin{array}{l}\text { Sample } \\
\text { reference } \mathrm{nr}\end{array}$ & $\begin{array}{l}\text { Outer bag } \\
\text { label }\end{array}$ & $\begin{array}{l}\text { Inner bag } \\
\text { label }\end{array}$ & Bone & $\begin{array}{c}\text { Mass } \\
(\mathrm{mg})\end{array}$ \\
\hline 8 & SM/C A7 L2 22.11.88 & BR014-01 & L. mandible & 110 \\
9 & $\mathrm{SM} /$ C AB5 L7 11.12.88 & BR021-01 & R. mandible & 101 \\
10 & SM/C B2 L4 3.12.88 & BR024-02 & L. femur & 111 \\
11 & SM/C D-E/1 baulk L8 10.12.88 & BR054-01 & L. mandible & 90 \\
12 & SM/C E1 L5 8.12.88 & BR057-01 & R. femur & 101 \\
13 & SM/C E4 L5 29.11.88 & BR061-01 & L. OS Innominatum & 94 \\
14 & SM/C E8 L4 23.11.88 & BR075-01 & R. femur & 140 \\
15 & SM/C F8 L6 28.11.88 & BR098-03 & R. tibia & 75 \\
16 & SM/C G4 L4 28.11.88 & BR103-01 & L. tibia & 150 \\
17 & SM/C I6 L8 14.12.88 & BR127-01 & L. femur & 170 \\
\hline
\end{tabular}

Table 2 Analytical data and AMS ${ }^{14} \mathrm{C}$ ages of rat bone from the Shag River Mouth site, New Zealand. XB samples are of "collagen"; these samples were pretreated at ANU and graphitized and AMS dated at ORAU. The samples are given OxA-V-nnn-nn numbers rather than OxA numbers because they were pretreated outside ORAU. The numbers denoted by $n$ refer to the AMS wheel number and the position of each sample in that specific wheel. NRC ("non-routine chemistry") denotes subsequent gelatinization of this XB fraction at ORAU. These ${ }^{14} \mathrm{C}$ determinations have been given OxA-X-nnn-nn numbers because of their non-routine chemistry. $\%$ carbon is the percent of carbon on combustion of gelatin or "collagen".

\begin{tabular}{|c|c|c|c|c|c|c|c|c|c|c|c|}
\hline OxA nr & $\begin{array}{l}\text { Sample } \\
\text { ref }\end{array}$ & $\begin{array}{l}\text { Bone wgt } \\
(\mathrm{mg})\end{array}$ & PCode & $\begin{array}{l}\% \text { wt. } \\
\text { collagen }\end{array}$ & $\begin{array}{l}\% \text { wt. } \\
\text { Nitrogen }\end{array}$ & $\begin{array}{l}\text { C mg } \\
\text { (wt dated) }\end{array}$ & $\begin{array}{l}\% \\
\text { carbon }\end{array}$ & $\mathrm{CN}$ & $\delta^{13} \mathrm{C}$ & $\delta^{15} \mathrm{~N}$ & $\begin{array}{l}\text { CRA (BP) } \\
( \pm 1 \sigma)\end{array}$ \\
\hline V-902-13 & 8 & 71.1 & XB & 10.5 & 12.24 & 2.9 & 37.4 & 3.6 & -13.9 & 17.8 & $985 \pm 55$ \\
\hline V-902-14 & 9 & 82.1 & $\mathrm{XB}$ & 12.0 & 14.72 & 2 & 41.9 & 3.3 & -20.2 & 11.6 & 45 \\
\hline X-932-07 & 10 & 71.8 & NRC & 12.8 & 16.00 & 0.4 & 39.5 & 2.9 & -20.4 & 13.5 & $555 \pm 70$ \\
\hline V-902-15 & 10 & & $\mathrm{XB}$ & & 14.02 & 4.5 & 42.1 & 3.5 & -19.1 & 18.3 & $655 \pm 55$ \\
\hline X-932-08 & 11 & 79.7 & NRC & 10.7 & 16.58 & 1.14 & 43.8 & 3.1 & -19.0 & 12.6 & $810 \pm 50$ \\
\hline V-904-05 & 11 & & XB & & 14.92 & 3.6 & 42.1 & 3.3 & -18.4 & 14.5 & $860 \pm 40$ \\
\hline X-959-09 & 12 & 85.6 & NRC & 13.2 & 13.57 & 1.4 & 37.1 & 3.2 & -19.8 & 12.9 & $855 \pm 65$ \\
\hline V-899-39 & 12 & & XB & & 15.47 & 3.6 & 43.5 & 3.3 & -19.6 & 12.9 & $760 \pm 37$ \\
\hline X-932-09 & 13 & 78.2 & NRC & 13.8 & 10.38 & 0.53 & 22.6 & 2.5 & -18.7 & 12.7 & $510 \pm 80$ \\
\hline V-904-06 & 13 & & XB & & 14.68 & 5.0 & 41.9 & 3.3 & -16.8 & 19.0 & $715 \pm 45$ \\
\hline$X-932-10$ & 14 & 109.5 & NRC & 13.1 & 17.59 & 2.2 & 45.4 & 3.0 & -15.1 & 16.3 & $720 \pm 55$ \\
\hline V-904-07 & 14 & & XB & & 14.43 & 3.0 & 42.9 & 3.5 & -13.5 & 17.3 & $950 \pm 40$ \\
\hline X-932-11 & 15 & 65.2 & NRC & 12.8 & 14.86 & 0.74 & 40.3 & 3.2 & -21.3 & 6.7 & $600 \pm 80$ \\
\hline V-904-08 & 15 & & XB & & 10.55 & 4.2 & 31.5 & 3.3 & -20.8 & 6.8 & $602 \pm 40$ \\
\hline$X-959-10$ & 16 & 114.2 & NRC & 13.4 & 37.86 & 1.03 & 106 & 3.3 & -20.5 & 6.8 & $600 \pm 45$ \\
\hline V-899-40 & 16 & & XB & & 15.52 & 6 & 30.8 & 3.2 & -20.1 & 7.6 & $631 \pm 40$ \\
\hline X-944-05 & 17 & 152.6 & NRC & 11.6 & 26.18 & 1.65 & 73.9 & 3.3 & -20.3 & 10.3 & $480 \pm 50$ \\
\hline V-905-33 & 17 & & $\mathrm{XB}$ & & 14.93 & 4.0 & 40.9 & 3.2 & -20.1 & 10.8 & $598 \pm 35$ \\
\hline
\end{tabular}

Sub-samples of this "collagen" were pretreated further at ORAU. Each was gelatinized in weakly acidic water (pH3) at $75^{\circ} \mathrm{C}$ for $20 \mathrm{hr}$, the supernatant was recovered using an EziFilter ${ }^{\mathrm{TM}}$ (readers should note that the EziFilters have been tested for old carbon contaminants in the light of the ultrafiltration problems outlined in Bronk Ramsey et al., these proceedings, and found to be free of extractable carbon) and lyophilized (Figure 3). In Table 2, and in the text, the gelatin samples are denoted with "NRC" pretreatment codes. Aliquots of both gelatin and "collagen" were analyzed for amino acid composition (Table 3 and Figure 4). 
Bone weighed, then cleaned with scalpel

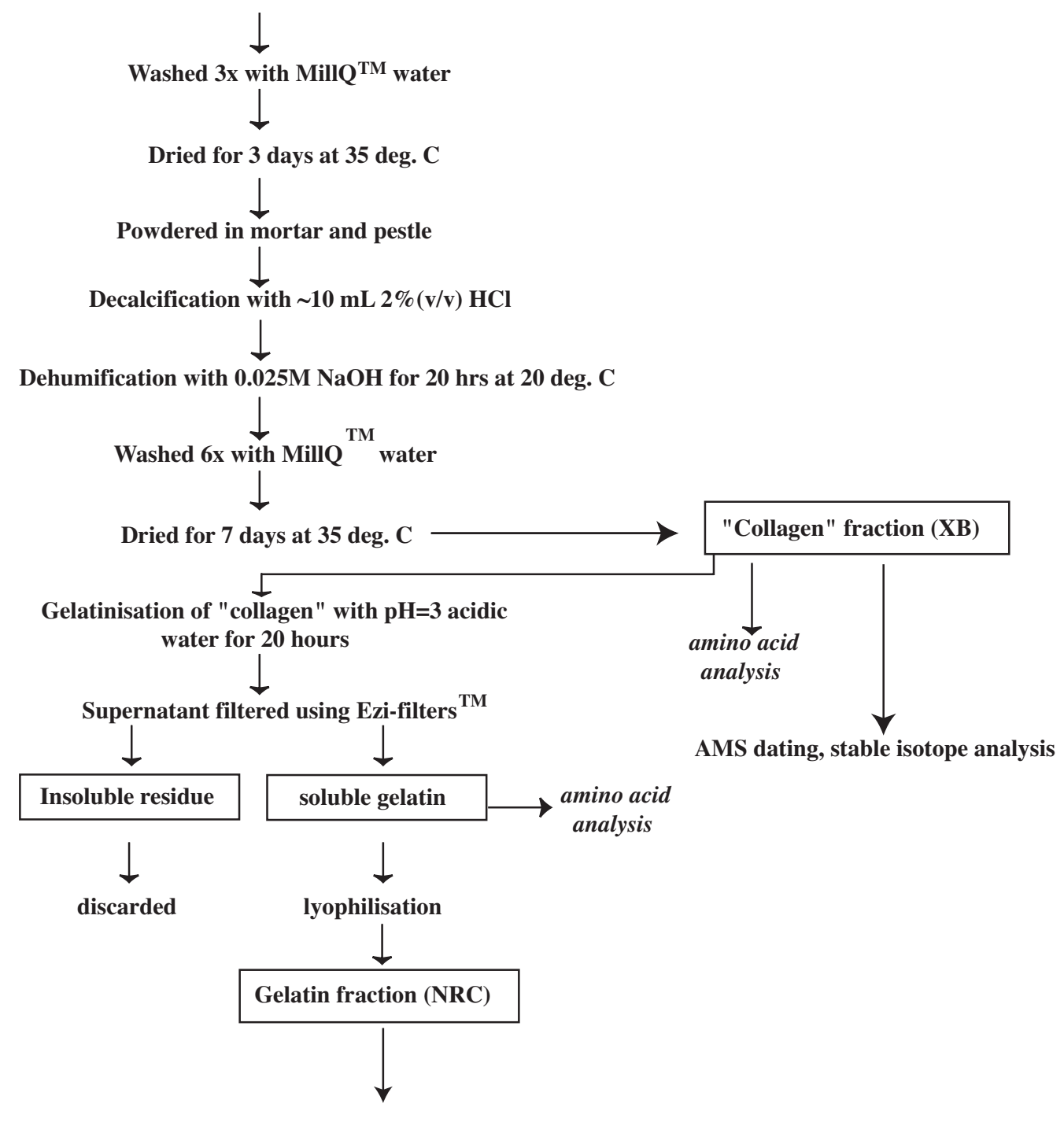

AMS dating, stable isotope analysis

Figure 3 Pretreatment flow diagrams describing pretreatments applied to the Shag River Mouth rat bones described in this paper.

Samples of between 0.5 and $1.8 \mathrm{mg}$ of bone gelatin were combusted and analyzed using a Europa Scientific ANCA-MS system consisting of a 20-20 IR mass spectrometer interfaced to a Roboprep $\mathrm{CHN}$ sample converter unit operating in continuous flow mode using an $\mathrm{He}$ carrier gas. This enables the measurement of $\delta^{15} \mathrm{~N}$ and $\delta^{13} \mathrm{C}$, nitrogen and carbon content, and $\mathrm{C}: \mathrm{N}$ ratios. $\delta^{13} \mathrm{C}$ values in this paper are reported with reference to VPDB, and $\delta^{15} \mathrm{~N}$ results are reported with reference to AIR (Coplen 1994). Graphite was prepared by reduction of $\mathrm{CO}_{2}$ over an iron catalyst in an excess $\mathrm{H}_{2}$ atmosphere at $560{ }^{\circ} \mathrm{C}$ prior to AMS ${ }^{14} \mathrm{C}$ measurement (Bronk Ramsey and Hedges 1999; Bronk Ramsey et al. 2000). 
Table $3{ }^{14} \mathrm{C}$ calibration age ranges at 68 and $95 \%$ ranges. Results were calibrated using OxCal 3.5 (Bronk Ramsey 2001) with the Southern Hemisphere calibration curve (Hogg et al. 2003; McCormac et al. 2003). No reservoir corrections have been applied in the calibration of any of the samples. See text for details.

\begin{tabular}{|c|c|c|c|c|c|}
\hline OxA nr & PCode & $\begin{array}{l}{ }^{14} \mathrm{C} \text { age } \\
\text { (BP) }\end{array}$ & $( \pm 1 \sigma)$ & $\begin{array}{l}\text { Calibrated age range } \\
\mathrm{AD} 1 \sigma\end{array}$ & $\begin{array}{l}\text { Calibrated age range } \\
\text { AD } 2 \sigma\end{array}$ \\
\hline V-902-13 & XB & 985 & 55 & $1025-1155$ & $\begin{array}{r}990-11010(3.6 \%) \\
1015-11210(91.8 \%)\end{array}$ \\
\hline V-902-14 & $\mathrm{XB}$ & 640 & 45 & $\begin{array}{l}1315-11360(45.8 \%) \\
1380-11405(22.4 \%)\end{array}$ & $1295-11420(95.4 \%)$ \\
\hline X-932-07 & $\mathrm{NRC}$ & 555 & 70 & $\begin{array}{l}1320-11345(10.1 \%) \\
1390-11455(58.1 \%)\end{array}$ & $\begin{array}{l}1295-11370(22.6 \%) \\
1375-11505(71.4 \%) \\
1595-11615(1.4 \%)\end{array}$ \\
\hline V-902-15 & $\mathrm{XB}$ & 655 & 55 & $\begin{array}{l}1300-11365(51.8 \%) \\
1375-11400(16.4 \%)\end{array}$ & $1285-11420(95.4 \%)$ \\
\hline $\mathrm{X}-932-08$ & $\mathrm{NRC}$ & 810 & 50 & $1220-11285(68.2 \%)$ & $\begin{array}{l}1175-11305(91.3 \%) \\
1355-11385(4.1 \%)\end{array}$ \\
\hline V-904-05 & $\mathrm{XB}$ & 860 & 40 & $\begin{array}{l}1180-11195(8.1 \%) \\
1205-11270(60.1 \%)\end{array}$ & $1155-11280(95.4 \%)$ \\
\hline X-959-09 & NRC & 855 & 65 & $\begin{array}{l}1160-11170\left(\begin{array}{c}2.8 \%) \\
1175-11280(65.4 \%)\end{array}\right.\end{array}$ & $\begin{array}{l}1040-11090(8.3 \%) \\
1100-11300(86.1 \%) \\
1365-11380\left(\begin{array}{c}1.0 \%)\end{array}\right.\end{array}$ \\
\hline V-899-39 & $\mathrm{XB}$ & 760 & 37 & $\begin{array}{l}1230-11245(3.8 \%) \\
1265-11305(47.3 \%) \\
1360-11380(17.1 \%)\end{array}$ & $\begin{array}{l}1225-11320(73.1 \%) \\
1350-11385(22.3 \%)\end{array}$ \\
\hline X-932-09 & $\mathrm{NRC}$ & 510 & 80 & $\begin{array}{l}1390-11505(63.2 \%) \\
1595-11615(5.0 \%)\end{array}$ & $\begin{array}{l}1315-11355(7.3 \%) \\
1380-11630(88.1 \%)\end{array}$ \\
\hline V-904-06 & $\mathrm{XB}$ & 715 & 45 & $\begin{array}{l}1285-11320(35.2 \%) \\
1350-11385(33.0 \%)\end{array}$ & $1270-11395(95.4 \%)$ \\
\hline$X-932-10$ & $\mathrm{NRC}$ & 720 & 55 & $\begin{array}{l}1280-11320(36.0 \%) \\
1350-11390(32.2 \%)\end{array}$ & $\begin{array}{l}1225-11250(3.5 \%) \\
1265-11400(91.9 \%)\end{array}$ \\
\hline V-904-07 & $\mathrm{XB}$ & 950 & 40 & $\begin{array}{l}1045-11085(26.6 \%) \\
1105-11120(5.7 \%) \\
1130-11185(32.9 \%) \\
1195-11210(3.1 \%)\end{array}$ & $1025-11215(95.4 \%)$ \\
\hline X-932-11 & $\mathrm{NRC}$ & 600 & 80 & $\begin{array}{l}1315-11360(27.4 \%) \\
1380-11440(40.8 \%)\end{array}$ & $1275-11480(95.4 \%)$ \\
\hline V-904-08 & $\mathrm{XB}$ & 602 & 40 & $\begin{array}{l}1320-11345(25.9 \%) \\
1390-11420(42.3 \%)\end{array}$ & $\begin{array}{l}1315-11360(36.9 \%) \\
1380-11445(58.5 \%)\end{array}$ \\
\hline$X-959-10$ & NRC & 600 & 45 & $\begin{array}{l}1320-11350(25.4 \%) \\
1385-11425(42.8 \%)\end{array}$ & $\begin{array}{l}1300-11365(37.5 \%) \\
1380-11445(57.9 \%)\end{array}$ \\
\hline V-899-40 & $\mathrm{XB}$ & 631 & 40 & $\begin{array}{l}1315-11355(44.0 \%) \\
1380-11405(24.2 \%)\end{array}$ & $\begin{array}{l}1295-11370(59.7 \%) \\
1375-11425(35.7 \%)\end{array}$ \\
\hline X-944-05 & $\mathrm{NRC}$ & 480 & 50 & $1420-11500(68.2 \%)$ & $\begin{array}{l}1400-11510(81.0 \%) \\
1545-11565(1.4 \%) \\
1570-11625(13.0 \%)\end{array}$ \\
\hline V-905-33 & $\mathrm{XB}$ & 598 & 35 & $\begin{array}{l}1320-11340(18.6 \%) \\
1390-11425(49.6 \%)\end{array}$ & $\begin{array}{l}1315-11355(31.7 \%) \\
1380-11440(63.7 \%)\end{array}$ \\
\hline
\end{tabular}



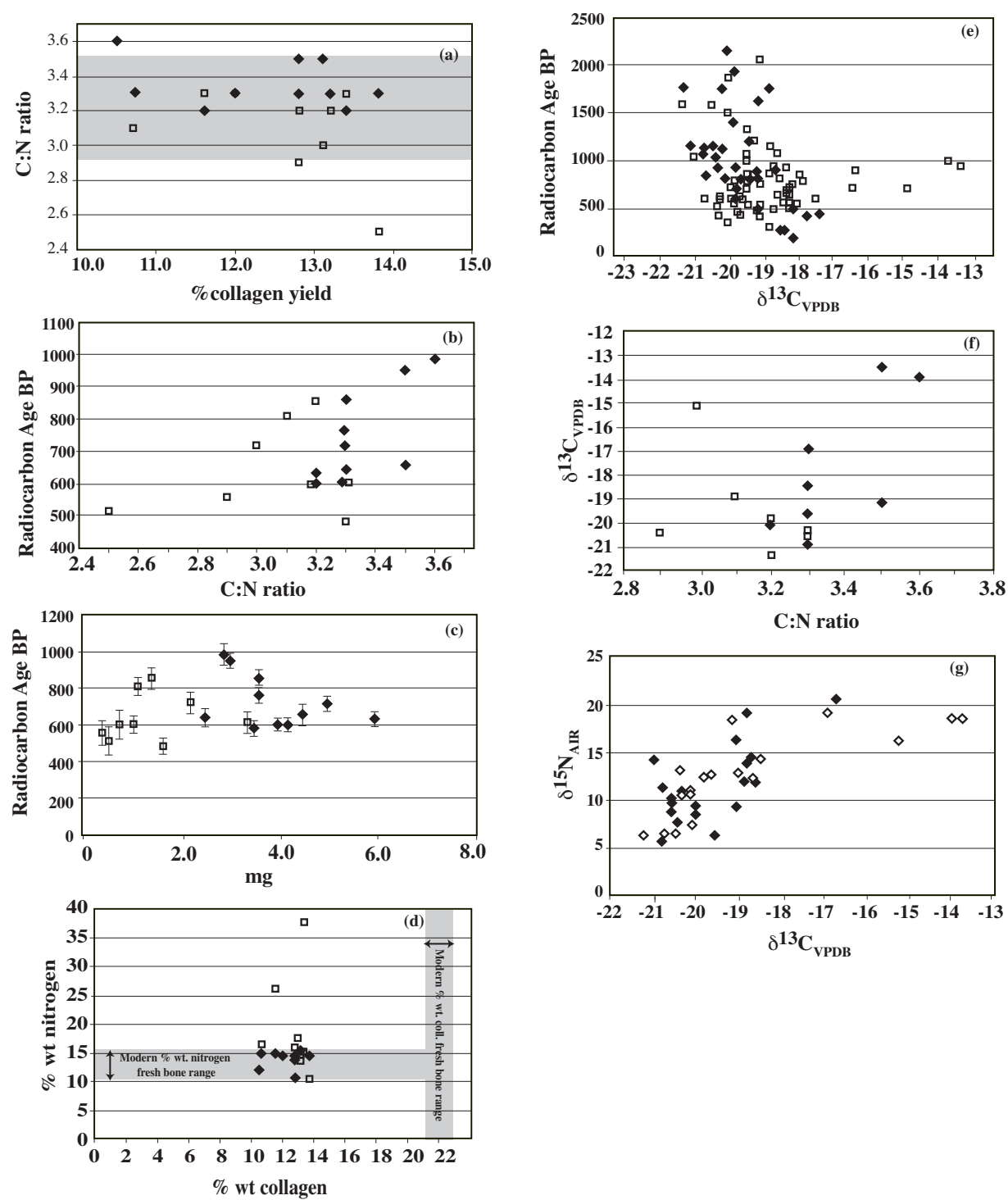

Figure 4 (a-g): for 4a-d and f; : denote XB collagen samples; $\square$ : denote NRC pretreated samples:

a) Correlation between $\mathrm{C}: \mathrm{N}$ ratio and collagen yield (\%). Shaded area represents the range of acceptability at ORAU (2.9-3.5).

b) $\mathrm{C}: \mathrm{N}$ ratio plotted against conventional ${ }^{14} \mathrm{C}$ age $\mathrm{BP}$.

c) Combusted gelatin size $(\mathrm{mg})$ plotted against conventional ${ }^{14} \mathrm{C}$ age $\mathrm{BP}$. There is no correlation between the size of the sample dated and their ${ }^{14} \mathrm{C}$ age. Gelatin weights were uniformly lower than collagen weights, but there is no discernible effect on corresponding ${ }^{14} \mathrm{C}$ age. This confirms earlier observations by Hedges (2000) for previous rat bone gelatin determinations

d) Relationship between $\%$ wt. nitrogen and $\%$ wt. collagen.

e) Conventional ${ }^{14} \mathrm{C}$ age BP plotted against $\delta^{13} \mathrm{C}$, all rat bone determinations. : denote "natural" bone samples; $\square$ : denote archaeological bone samples.

f) C:N ratio plotted against $\delta^{13} \mathrm{C}$ for samples described in this paper.

g) $\delta^{15} \mathrm{~N}$ versus $\delta^{13} \mathrm{C}$ for all archaeological rat bone samples dated (expressed in \%o). $\diamond$ : denote samples of "collagen" and gelatin published in this study, $\bullet$ : denote samples from other archaeological contexts where there is comparable isotopic data (taken from Anderson 1996; Smith and Anderson 1998; Beavan-Athfield et al. 1999). 


\section{RESULTS}

The ${ }^{14} \mathrm{C}$ ages (Tables 2 and 3) obtained range from about 480 to $980 \mathrm{BP}$. Compared with the first series of rat bones dated at the Rafter Radiocarbon Laboratory, IGNS (Anderson 1996), these are closer in age to that expected archaeologically, but they do show variance as a group. This is especially evident when the close agreement apparent from reliable samples such as charcoal and marine or estuarine shell is considered (Figure 2). We evaluate below the analytical data associated with each AMS measurement, particularly the effect of pretreatment methods upon single rat bones and the differences between "collagen" (XB) and gelatin (NRC) fractions.

The preservation state of the Shag River rat bones is important in assessing the reliability of the ${ }^{14} \mathrm{C}$ results. In instances where bone preservation is poor and the collagen yield is low, it is likely that the proportional effect of contaminants will increase if the contamination in a site is assumed to be present in a constant amount. Petchey and Higham (2000) found that bone from the Shag River site varied with location and that bone from low-lying margins adjacent to the mudflats was less wellpreserved than bone from higher dune areas, such as at SM/C:Dune.

Each batch of the pretreated samples from this area that we analyzed produced "collagen" yields between $10-14 \%$ of the original bone weight (Table 2). This suggests that between $50-75 \%$ of the original collagen remains (mean $=62.9 \pm 6.8 \%$ ), which places these samples in Hedges and van Klinken's $(1992: 282,284)$ "transitional preservation" category. The \% weight nitrogen is within the ranges expected for unaltered or intact collagen (van Klinken 1999) (Figure 3g) with the exception of 2 samples which have much higher measured nitrogen. Percent carbon yields of combusted gelatin and "collagen" range between $30-50 \%$ as expected, with 2 exceptions.

While $\mathrm{C}: \mathrm{N}$ atomic ratios are not sensitive to the uptake of small amounts of non-collagenous contamination, they will show gross exogenous contamination, particularly where the $\mathrm{C}: \mathrm{N}$ ratio of the contaminating fraction is significantly different from bone collagen. $\mathrm{C}: \mathrm{N}$ ratios greater than 3.6 may be taken as evidence for the presence of $\sim 5-20 \%$ added contamination. C:N atomic ratios between 2.9-3.5 are considered acceptable at ORAU. The C:N ratios for the "collagen" series ranged between 3.2-3.6, while for the gelatin series the range was 2.9-3.3, with 1 value of 2.5. Van Klinken (1999) found that higher C:N ratios and lower \% wt. collagen yields correlated closely with problematic bones. While the "collagen" samples show a slightly higher correlation between increased $\mathrm{C}: \mathrm{N}$ ratios and lower \% wt. collagen yields than the gelatin series, the evidence is not convincing (Figure 4a); the collagen yields are not excessively low.

The C:N ratios, the $\delta^{13} \mathrm{C}$ and $\delta^{15} \mathrm{~N}$ values, and the ${ }^{14} \mathrm{C}$ ages together suggest the presence of a contaminant that may have affected some of the "collagen" samples. The higher $\mathrm{C}: \mathrm{N}$ ratios associated with some of them (Figure 4b) tend to be associated both with the oldest ${ }^{14} \mathrm{C}$ ages and more enriched $\delta^{13} \mathrm{C}$ values, and the gelatinization pretreatment of the same bone resulted in younger ${ }^{14} \mathrm{C}$ ages, less enriched $\delta^{13} \mathrm{C}$ values, and reduced C:N ratios in 2 cases (for example, Sample refs 14 and 13 and perhaps also 10 [Table 2]). This suggests that simple gelatinization and filtration has removed a significant proportion of the contaminants. The high C:N ratios in the "collagen" series supports the addition of a proportion of non-proteinaceous contaminants, probably insoluble sediments, also removed by the later pretreatment. The results for bones of sample numbers 13 and 14 suggest also that contaminants in some bones are of marine origin (Table 2). In some instances, the shift in stable isotope results from XB to NRC pretreatment is as high as $6 \%$ in $\delta^{15} \mathrm{~N}$.

Amino acid profiles obtained from both pretreated fractions provide support for the presence of contaminants in some of the bones. They show that the XB series are largely non-collagenous in their composition. This implies the addition of a proteinaceous but non-collagenous contaminant (Figure 
5, Table 4). Gelatinization and filtration pretreatment effectively removes this contamination. The amino acid profiles for the NRC sample fractions are typical of collagen. Taken together, the C:N, $\delta^{13} \mathrm{C}$, and amino acid data suggest that there is a non-proteinaceous contaminant, as well as a proteinaceous but non-collagenous contaminant within the "collagen" sample fractions, which is significantly reduced in the gelatin fractions.

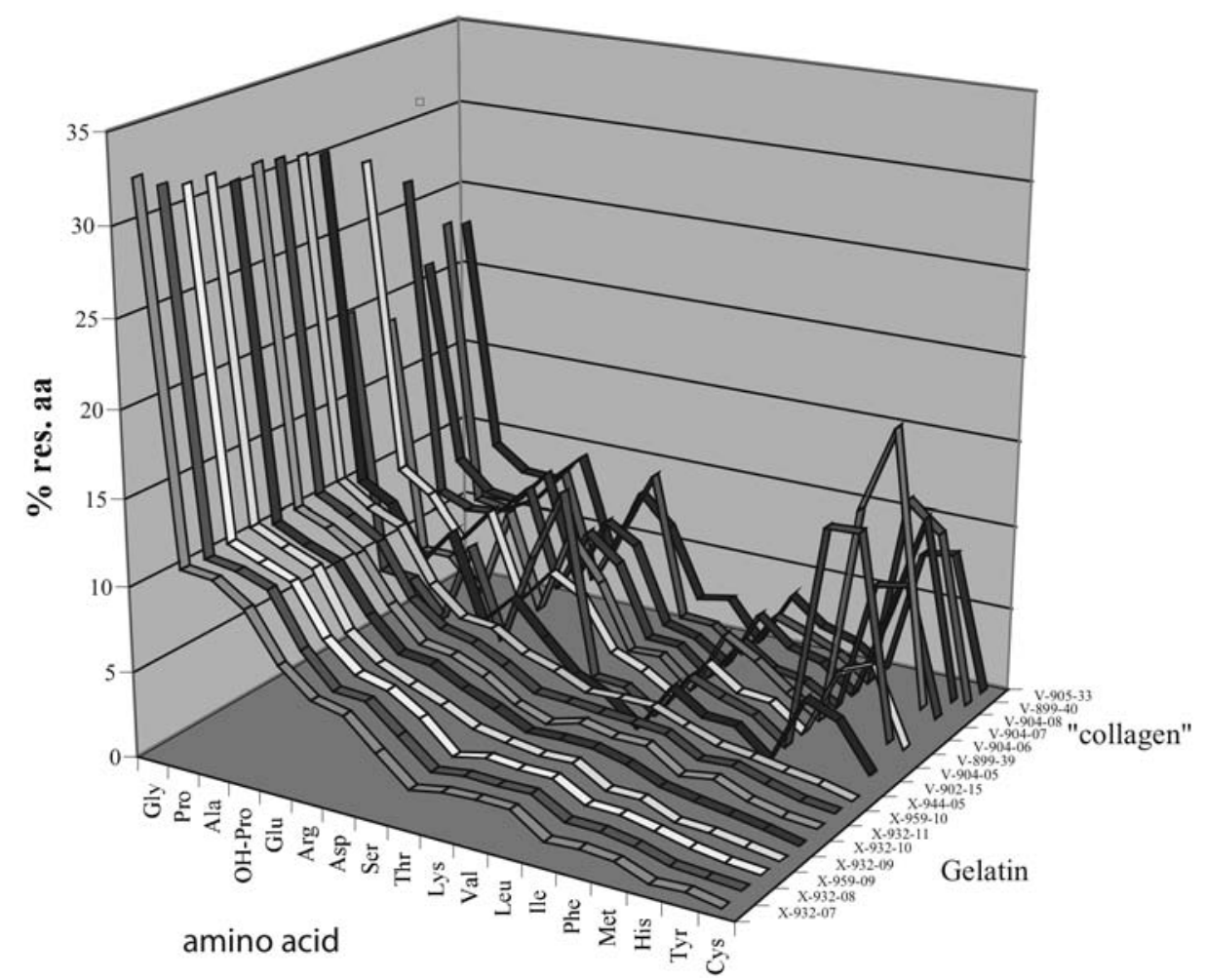

Figure 5 Amino acid profiles of rat bone gelatin (NRC) and "collagen" (XB) from Shag River Mouth; see text for details.

$\delta^{15} \mathrm{~N}$ values reflect sources for dietary protein, and since there is an enrichment in $\delta^{15} \mathrm{~N}$ from dietary protein to bone collagen of 3-4\%, important information concerning trophic level and food webs is able to be obtained from nitrogen stable isotope analyses. The $\delta^{15} \mathrm{~N}$ values for gelatin ranged from $6.7-16.3 \%$, indicating the uptake of a wide range of dietary protein from a range of sources and trophic levels, as one might expect in this species. Two rat bones yielded $\delta^{15} \mathrm{~N}$ values of $6-7 \%$ (Table 2) which are consistent with the uptake of the major proportion of dietary protein from terrestrial plant sources. These are paired with $\delta^{13} \mathrm{C}$ values which are terrestrial $(-20.5$ and $-21.3 \%)$. One rat yielded a $\delta^{15} \mathrm{~N}$ value of $10.3 \%$, again with a terrestrial $\delta^{13} \mathrm{C}$, which indicates dietary protein dominated by terrestrial herbivore flesh, probably land birds, which were extensively consumed by humans at the site (Anderson et al. 1996a). Two rats produced stable isotopic signatures (sample refs 8 and 14) which indicated significant marine protein uptake, again unsurprising given the high amount of marine foods consumed at the site by people (MNI estimates of Shag River faunal remains suggest marine foods comprise $15-35 \%$ of the total meat weight consumed at the site [Anderson et al. 1996a]). $\delta^{15} \mathrm{~N}$ values above $11 \%$ may indicate the influence of protein derived through aquatic or freshwater ecosystem foodwebs, since enrichment in $\delta^{15} \mathrm{~N}$ is not paralleled by enrichment in $\delta^{13} \mathrm{C}$ values (Beavan-Athfield and Sparks 2001). 
Table 4 Amino acid compositions (\% residues) for selected Shag River Mouth rat bones. Samples were analyzed on an $\mathrm{ABI} 420 \mathrm{~A}$ derivatiser/analyser (PE Biosystems, Warrington, UK) following hydrolysis for $24 \mathrm{hr}$ in $5.7 \mathrm{~N} \mathrm{HCl}$ at $110^{\circ} \mathrm{C}$ (Heinrikson and Meredith 1984).

\begin{tabular}{lrrrrrrrrrrrrrrrrrr}
\hline GELATIN & Gly & Pro & Ala & OH-P & Glu & Arg & Asp & Ser & Thr & Lys & Val & Leu & Ile & Phe & Met & His & Tyr & Cys \\
\hline X-932-07 & 32.5 & 11.3 & 11.2 & 9.9 & 7.2 & 5.6 & 5.2 & 3.6 & 2.0 & 2.4 & 2.4 & 2.4 & 1.1 & 1.2 & 1.1 & 0.3 & 0.5 & 0.1 \\
X-932-08 & 31.6 & 11.2 & 11.0 & 10.3 & 7.3 & 5.4 & 5.3 & 3.8 & 2.2 & 2.4 & 2.4 & 2.4 & 1.4 & 1.3 & 1.0 & 0.5 & 0.3 & 0.2 \\
X-959-09 & 31.2 & 11.5 & 10.7 & 10.1 & 7.2 & 5.6 & 5.1 & 4.0 & 2.2 & 2.6 & 2.5 & 2.5 & 1.4 & 1.4 & 1.0 & 0.6 & 0.3 & 0.1 \\
X-932-09 & 31.2 & 11.7 & 10.9 & 10.2 & 6.8 & 5.4 & 4.6 & 3.9 & 3.1 & 2.7 & 2.5 & 2.5 & 1.4 & 1.4 & 0.6 & 0.6 & 0.3 & 0.0 \\
X-932-10 & 30.5 & 11.3 & 10.4 & 9.7 & 7.1 & 5.3 & 5.1 & 4.1 & 3.4 & 2.5 & 2.6 & 2.6 & 2.1 & 1.4 & 1.0 & 0.7 & 0.4 & 0.0 \\
X-932-11 & 31.0 & 11.5 & 10.7 & 9.6 & 7.0 & 5.1 & 4.9 & 4.1 & 2.9 & 2.2 & 2.7 & 2.4 & 2.4 & 1.1 & 1.4 & 0.6 & 0.3 & 0.1 \\
X-959-10 & 30.8 & 11.6 & 10.7 & 9.6 & 6.6 & 5.3 & 4.9 & 3.9 & 2.8 & 2.7 & 2.5 & 2.4 & 2.3 & 1.2 & 1.4 & 0.8 & 0.3 & 0.1 \\
X-944-05 & 30.5 & 11.8 & 10.6 & 9.9 & 6.8 & 5.2 & 5.0 & 3.9 & 3.3 & 2.5 & 2.6 & 2.6 & 1.9 & 1.3 & 1.0 & 0.7 & 0.4 & 0.0 \\
& & & & & & & & & & & & & & & & & & \\
COLLAGEN & & & & & & & & & & & & & & & & & \\
V-902-15 & 30.2 & 11.1 & 10.0 & 7.0 & 9.2 & 4.2 & 6.1 & 4.1 & 2.3 & 1.5 & 0 & 2.9 & 1.7 & 1.6 & 0 & 4.0 & 3.3 & 0.6 \\
V-904-05 & 20.3 & 5.0 & 4.8 & 2.7 & 7.7 & 2.3 & 7.8 & 12.1 & 1.4 & 1.2 & 0 & 2.8 & 2.0 & 1.4 & 0 & 13.3 & 13.4 & 1.7 \\
V-899-39 & 28.8 & 10.6 & 9.4 & 7.0 & 9.2 & 4.1 & 6.2 & 5.2 & 2.2 & 1.5 & 0.3 & 2.9 & 1.6 & 1.4 & 0 & 4.2 & 5.0 & 0.5 \\
V-904-06 & 18.8 & 4.9 & 4.9 & 3.0 & 8.4 & 2.8 & 7.8 & 5.3 & 1.5 & 1.6 & 0 & 3.8 & 2.7 & 1.2 & 0 & 12.9 & 18.0 & 2.1 \\
V-904-07 & 26.7 & 7.9 & 7.2 & 7.4 & 9.2 & 3.4 & 7.3 & 5.7 & 1.6 & 1.5 & 0 & 2.7 & 1.4 & 1.1 & 0 & 7.8 & 8.2 & 0.8 \\
V-904-08 & 21.2 & 9.2 & 7.6 & 7.4 & 9.5 & 3.4 & 7.3 & 6.3 & 1.7 & 1.3 & 0 & 3.6 & 2.0 & 1.5 & 0 & 5.5 & 11.5 & 1.0 \\
V-899-40 & 23.2 & 6.1 & 5.8 & 6.8 & 8.9 & 2.6 & 6.2 & 9.9 & 1.4 & 1.4 & 0 & 2.7 & 2.1 & 1.3 & 0 & 11.5 & 9.9 & 0 \\
V-905-33 & 22.7 & 9.0 & 7.7 & 7.5 & 9.3 & 3.6 & 7.8 & 6.0 & 1.9 & 2.3 & 0 & 3.3 & 1.8 & 1.3 & 0 & 7.6 & 8.0 & 0 \\
\hline
\end{tabular}

The ${ }^{14} \mathrm{C}$ dates show that the contaminants we have identified in the "collagen" fractions do not appear to be of a significantly different age. The gelatin pretreated samples appear slightly younger in age than their paired "collagen" pretreated samples, but in only 2 cases is this statistically significant (sample references 13 and 14). When the calibrated ${ }^{14} \mathrm{C}$ age ranges are compared, there is overlap in all paired samples except one (sample 14).

\section{CONCLUSIONS}

The earlier set of rat bone AMS dates from Shag River Mouth disclosed significant variation in comparison with our series (Figure 2). The precise reason, or reasons for this, remain elusive, however, some possibilities are able to be set to one side. The first is contamination. The results of our analysis suggest that there is some contamination within bone from the area of the SM/C:Dune site, but this does not appear to be present in sufficiently large proportion to produce ages which approach those previously obtained (Anderson 1996). This conclusion is supported by the general agreement between the conventional ${ }^{14} \mathrm{C}$ ages of the majority of the pretreated pairs. In only one instance was the difference between pairs significant. This supports the data obtained by Higham (1993) which showed that ${ }^{14} \mathrm{C}$ determinations of humic contaminants were identical in age to those of treated and unpretreated charcoal from SM/C:Dune (see also Anderson et al. 1996b).

Analytical data $(\% \mathrm{C}, \% \mathrm{~N}, \mathrm{C}: \mathrm{N}$ atomic ratios, \% wt. collagen) supported the notion that the bones were of "transitional preservation." Each NRC-pretreated batch of bone yielded "collagen" ranging between 10-14 wt. \%. This was supported by C:N ratios of 2.9-3.3, which fall within the accepted thresholds at Oxford, with 1 exception which was not reflected in a significant difference in ${ }^{14} \mathrm{C}$ age. We found that the application of 2 pretreatment methods affected the collagenous composition as shown by amino acid profiles, but this did not result in ages which were significantly different statistically.

Although the majority of AMS determinations of rat gelatin are in broad agreement with those of other materials, a small number suggest a probable reservoir depletion may exist. The stable isotope 
values of OxA-X-932-10 (gelatin), for instance, show that this rat consumed protein derived from marine organisms, such as fish and shellfish, and this is consistent with an older offset. We have not applied any reservoir correction to the result because of uncertainty regarding the proportion of an offset to apply. Beavan-Athfield and Sparks (2001) applied a reservoir correction to rat bone determinations from Pleasant River Mouth, but clear anomalies resulted once the recalibrated data were obtained; one result, for instance, became much too young for the age of the site, while another remained much too old. Beavan-Athfield and Sparks (2001) argued that reservoir anomalies identified on the basis of dual $(\mathrm{C}, \mathrm{N})$ isotope analysis alone may be difficult to interpret with confidence, since foods consumed from aquatic, riverine, marine, and terrestrial environments often overlap in their isotopic range. This is particularly relevant when various protein sources from plants and animals of a variety of reservoirs are being consumed. In the case of the Shag River site, the dating of a large number of rat bones in parallel with carbon and nitrogen isotopic analysis has shown that there are small reservoir effects, but none which exceed the size of the marine reservoir effect. Three bones (sample refs 15, 16, and 17; Table 2) are likely to be unaffected by reservoir offsets since their $\delta^{15} \mathrm{~N}$ and $\delta^{13} \mathrm{C}$ values are terrestrial in nature. Judging by the rat bone dates presented here and the age of the site as determined by other materials, no reservoir effects of the magnitude required to correct the early dated series of Anderson (1996) are apparent.

These results are in sharp contrast with previously obtained rat ${ }^{14} \mathrm{C}$ dates from the same contexts at this site (Anderson 1996). Although we have detected the presence of contaminants in the bones, and also of minor reservoir effects on the ${ }^{14} \mathrm{C}$ ages, the overall influence on the resultant dates are relatively slight. We would argue that these results, which are in broad agreement with ${ }^{14} \mathrm{C}$ dating of other materials from the site, cast doubt on the earlier published series. In the light of these results, we feel the case for rats being present in New Zealand prior to established human settlement as outlined by Holdaway $(1996,1999)$ remains to be proven.

\section{ACKNOWLEDGEMENTS}

We acknowledge the careful assistance of A Bowles, M Humm, P Leach, and C Tompkins (ORAU) in preparation of samples for AMS dating. T Willis, MRC Immunochemistry Unit, University of Oxford, prepared the amino acid analyses. We thank two anonymous reviewers for their constructive comments.

\section{REFERENCES}

Anderson AJ. 1991. The chronology of colonisation in New Zealand. Antiquity 65:767-95.

Anderson AJ. 1996. Was Rattus exulans in New Zealand 2000 years ago? AMS radiocarbon ages from Shag River Mouth. Archaeology in Oceania 31:178-84.

Anderson AJ, Allingham BJ, Smith IWG, editors. 1996a. Shag River Mouth: The Archaeology of an Early Southern Maori Village. Canberra: Australian National University Research Papers in Archaeology and Natural History 27.

Anderson AJ, Smith IWG, Higham TFG. 1996b. Radiocarbon chronology. In: Shag River Mouth: The Archaeology of an Early Southern Maori Village. In: Anderson AJ, Allingham BJ, Smith IWG, editors. 1996. Shag River Mouth: The Archaeology of an Early Southern Maori Village. Canberra: Australian National University Research Papers in Archaeology and
Natural History 27. p 60-9.

Beavan-Athfield NR, McFadgen BG, Sparks RJ. 1999. Reliability of bone gelatin AMS dating: Rattus exulans and marine shell radiocarbon dates from Pauatahanui midden sites in Wellington, New Zealand. Radiocarbon 41(2):119-26.

Beavan-Athfield N, Sparks RJ. 2001. Dating of Rattus exulans and bird bone from Pleasant River (Otago, New Zealand): radiocarbon anomalies from diet. Journal of the Royal Society of New Zealand 31(4): 801-9.

Bronk Ramsey C. 2001. Development of the radiocarbon calibration program OxCal. Radiocarbon 43(2A): 355-63.

Bronk Ramsey C, Hedges REM. 1999. Hybrid ion sources: radiocarbon measurements from microgram to milligram. Nuclear Instruments and Methods in 
Physics Research B 123:539-45.

Bronk Ramsey C, Higham TFG, Bowles A, Hedges REM. 2004. Improvements to the pretreatment of bone at Oxford. Radiocarbon, these proceedings.

Bronk Ramsey C, Pettitt PB, Hedges REM, Hodgins GWL, Owen DC. 2000. Radiocarbon dates from the Oxford AMS system: Archaeometry Datelist 30. Archaeometry 42:459-79.

Coplen TB. 1994. Reporting of stable hydrogen, carbon and oxygen isotopic abundances. Pure and Applied Chemistry 66:273-6.

DeNiro MJ, Weiner S. 1988. Chemical, enzymatic and spectroscopic characterisation of "collagen" and other organic fractions from prehistoric bones. Geochimica et Cosmochimica Acta 52:2197-206.

Hedges REM. 2000. Appraisal of radiocarbon dating of kiore bones (Pacific rat Rattus exulans) in New Zealand. Journal of the Royal Society of New Zealand 30(4):385-98.

Hedges REM, van Klinken GJ. 1992. A review of current approaches in the pretreatment of bone for radiocarbon dating by AMS. Radiocarbon 34(3):279-91.

Heinrikson RL, Meredith SC. 1984. Amino-acid-analysis by reverse-phase high-performance liquid-chromatography - precolumn derivatization with phenylisothiocyanate. Analytical Biochemistry 136:65-74.

Higham TFG. 1993. Radiocarbon Dating the Prehistory of New Zealand [PhD dissertation]. Waikato: University of Waikato.

Higham TFG. 1994. Radiocarbon dating New Zealand prehistory with Moa eggshell: some preliminary results. Quaternary Geochronology (Quaternary Science Reviews) 13:163-9.

Higham TFG, Anderson AJ, Jacomb C. 1999. Dating the first New Zealanders: the chronology of Wairau Bar. Antiquity 73:420-7.

Higham TFG, Hogg AG. 1995. Radiocarbon dating of prehistoric shell from New Zealand and calculation of the $\Delta \mathrm{R}$ value using fish otoliths. Radiocarbon 37(2): 409-16.

Higham TFG, Petchey FP. 2000. On the reliability of rat bone for dating in New Zealand. Journal of the Royal Society of New Zealand 30(4):399-409.

Hogg AG, McCormac FG, Higham TFG, Reimer PJ, Baillie MGL, Palmer JG. 2003. High-precision radiocarbon measurements of contemporaneous tree-ring dated wood from the British Isles and New Zealand: AD 1850-950. Radiocarbon 44(3):633-40.
Holdaway RN. 1996. Arrival of rats in New Zealand. $\mathrm{Na}$ ture 384:225-6.

Holdaway RN. 1999. A spatio-temporal model for the invasion of the New Zealand archipelago by the Pacific rat Rattus exulans. Journal of the Royal Society of New Zealand 29(2):91-105.

Holdaway RN, Beavan NR. 1999. Reliable ${ }^{14} \mathrm{C}$ AMS dates on bird and Pacific rat Rattus exulans bone gelatin, from a $\mathrm{CaCO}_{3}$-rich deposit. Journal of the Royal Society of New Zealand 29(3):185-211.

McCormac FG, Hogg AG, Higham TFG, Baillie MGL, Palmer JG, Xiong L, Pilcher JR, Brown D, Hoper S. 1998. Variations of radiocarbon in tree rings: Southern Hemisphere offset preliminary results. Radiocarbon 40(3):1153-9.

McCormac FG, Reimer PJ, Hogg AG, Higham TFG, Baillie MGL, Palmer JG, Stuiver M. 2003. Calibration of the radiocarbon timescale for the Southern Hemisphere: AD 1850-950. Radiocarbon 44(3):641-51.

McFadgen BG. 1996. Topography and geomorphology of the Shag River sand spit. In: Anderson AJ, Allingham BJ, Smith IWG, editors. Shag River Mouth: the Archaeology of an Early Southern Maori Village. Canberra: Australian National University Research Papers in Archaeology and Natural History 27. p 14-20.

Petchey FJ. 1998. Radiocarbon Analysis of a Novel Bone Sample Type: Snapper and Barracuda Bone from New Zealand Archaeological Sites [PhD dissertation]. Waikato: University of Waikato.

Petchey FJ, Higham TFG. 2000. Bone diagenesis and radiocarbon dating of fish bones at the Shag River Mouth site, New Zealand. Journal of Archaeological Science 27:135-50.

Smith IWG, Anderson AJ. 1998. Radiocarbon dates from archaeological rat bones: the Pleasant River case. Archaeology in Oceania 33:88-91.

Stafford TW Jr, Brendel K, Duhamel RC. 1988. Radiocarbon ${ }^{13} \mathrm{C}$ and ${ }^{15} \mathrm{~N}$ analysis of fossil bone: removal of humates with XAD-2 resin. Geochimica et Cosmochimica Acta 52:2257-67.

Stuiver M, Reimer PJ, Bard E, Beck JW, Burr GS, Hughen KA, Kromer B, McCormac FG, van der Plicht J, Spurk M. 1998. INTCAL98 radiocarbon age calibration, 24,000-0 cal AD. Radiocarbon 40(3):1041-83.

van Klinken GJ. 1999. Bone collagen quality indicators for palaeodietary and radiocarbon measurements. Journal of Archaeological Science 26:687-95. 